\title{
Feeding a higher plane of nutrition and providing exogenous estrogen increases mammary gland development in Holstein heifer calves
}

\author{
A. J. Geiger, C. L. M. Parsons, and R. M. Akers ${ }^{1}$ \\ Department of Dairy Sciences, Virginia Polytechnic Institute and State University, Blacksburg 24061
}

\begin{abstract}
Feeding heifers a higher plane of nutrition postweaning but before puberty can negatively affect mammary gland development and future milk yield. However, enhanced nutrition preweaning may promote development and future production. Our objectives were to determine the effects of enhanced feeding preweaning and exogenous estrogen immediately postweaning on mammary gland development and the composition of the mammary parenchyma (PAR) and mammary fat pad (MFP). Thirty-six Holstein heifer calves $(<1 \mathrm{wk}$ old) were reared on 1 of 2 dietary treatments for $8 \mathrm{wk}$ : (1) a restricted milk replacer fed at $0.45 \mathrm{~kg} / \mathrm{d}(\mathrm{R} ; 20 \%$ crude protein, $20 \%$ fat), or (2) an enhanced milk replacer fed at $1.13 \mathrm{~kg} / \mathrm{d}$ (EH; $28 \%$ crude protein, $25 \%$ fat). Upon weaning, calves from each diet $(n=6)$ were given either a placebo or estrogen implant for $2 \mathrm{wk}$, creating 4 treatments: R, R + estrogen (R-E2), EH, and $\mathrm{EH}+$ estrogen $\left(\mathrm{EH}-\mathrm{E}_{2}\right)$. Calves were housed individually with ad libitum access to water. Starter feeding began at wk 5 and was balanced between treatments. Udders were evaluated by palpation and physical measurements weekly. Subsets of calves were killed at weaning $(\mathrm{n}=$ 6 per diet) and at the conclusion of the trial $(\mathrm{n}=6$ per treatment). Udders were removed, dissected, and weighed. At wk 8, EH calves had longer front and rear teats. Providing estrogen to $\mathrm{EH}$ calves increased the length of rear teats during wk 9 and 10. Enhanced-fed calves had 5.2-fold more trimmed mammary gland mass than R calves. Providing estrogen to EH calves further increased mammary gland weight. Masses of PAR and MFP were markedly greater for $\mathrm{EH}$ calves than for $\mathrm{R}$ calves (e.g., 7.3-fold greater PAR tissue). Estrogen increased the mass of both PAR and MFP in EH calves. Feeding a higher plane of nutrition increased total protein, DNA, and fat in the MFP and total protein and DNA in the PAR. Dual-energy x-ray absorptiometry
\end{abstract}

Received April 6, 2016.

Accepted May 27, 2016.

${ }^{1}$ Corresponding author: rma@vt.edu estimates of mammary fat mass were highly correlated with biochemical analyses of fat content. From histological study, we observed that the degree of expansion of epithelium into the adjacent stromal tissue and the complexity of ductal development were minimal in $\mathrm{R}$, increased in $\mathrm{EH}$, and increased by estrogen in both dietary treatments. Results provide compelling evidence that preweaning nutrition and estrogen administration immediately postweaning markedly increase mammary gland development in dairy calves. Cellular and molecular mechanisms responsible for these differences are currently under study.

Key words: mammary gland, milk replacer, estrogen, calf

\section{INTRODUCTION}

The expense of raising heifers accounts for about $20 \%$ of annual dairy farm costs (Heinrichs, 1993). Consequently, producers seek to have heifers calve as early as practically possible to decrease their nonproductive period of life. To achieve earlier calving, heifers must reach puberty at an earlier age. Because puberty and BW are highly correlated, early puberty and calving can be achieved by increasing rates of gain (Sejrsen et al., 1982; USDA, 2007).

However, it is widely reported that an excessive rate of gain during the prepubertal period, which can sometimes result from trying to get calves to their pubertal BW earlier, can impair mammary growth and reduce future milk yield (Sejrsen et al., 1982; Lammers et al., 1999; Radcliff et al., 2000). Precise mechanisms responsible for these effects are not completely understood but are likely a combination of a shorter peripubertal allometric mammary growth phase and altered responses to mammogenic stimuli [e.g., estrogen $\left(\mathbf{E}_{2}\right)$; Meyer et al., 2006a,b], or both.

Before weaning, the dairy calf consumes a nutrientdense, milk-based diet. During this time, feeding for an increased rate of gain does not impair mammary development (Daniels et al., 2009a). In fact, several studies (Brown et al., 2005; Meyer et al., 2006b) suggest that a higher plane of nutrition preweaning can stimulate 
mammary development. Soberon et al. (2012) reported that increasing ADG by $1 \mathrm{~kg} / \mathrm{d}$ during the preweaning period was correlated with an increase in first-lactation milk yield of more than $1,000 \mathrm{~kg}$. Additionally, as emphasized in the comprehensive review by Khan et al., (2011), improved preweaning nutrition benefits not only the growth but also the health and performance of the dairy calf.

Although the mechanisms responsible for the positive correlation between preweaning gain and future milk potential are unknown, it is clear that mammary gland development during early life is essential to future productivity. Consensus was that mammary parenchyma (PAR) growth was minimal during the preweaning period, until the onset of allometric mammary growth before puberty (Sinha and Tucker, 1969), but recent data have shown that allometric growth of the mammary PAR begins much earlier than once believed. Indeed, PAR mass can increase 60-fold from $30 \mathrm{~d}$ until approximately $90 \mathrm{~d}$ of life (Capuco and Akers, 2010; Esselburn et al., 2015).

Our hypothesis is that providing heifers with a higher plane of nutrition during the preweaning period creates a mammary gland and mammary cells that are primed to respond more readily to mammogenic stimuli. Estrogens are classic mammogenic hormones produced primarily by the ovaries (Yart et al., 2014). Moreover, mammary tissue in prepubertal ruminants is sensitive to $\mathrm{E}_{2}$ (Woodward et al., 1993; Ellis et al., 1998; Capuco et al., 2002). Despite the fact that circulating concentrations of $\mathrm{E}_{2}$ are very low in prepubertal calves (Purup et al., 1993; Velayudhan et al., 2012, 2015) when $\mathrm{E}_{2}$ influence is removed from the calf via ovariectomy or the use of an $\mathrm{E}_{2}$ receptor antagonist, mammary gland development is markedly reduced (Berry et al., 2003; Tucker et al., 2016). Perhaps enhanced early nutrition augments the action of mammogenic stimuli (such as $\mathrm{E}_{2}$ ); for this reason, we selected $\mathrm{E}_{2}$ to test our hypothesis.

Lammers et al. (1999) assessed the effects of exogenous $\mathrm{E}_{2}$ and plane of nutrition on mammary gland development in older heifers beginning at 4.5 mo of age over a period of $20 \mathrm{wk}$. They noted that $\mathrm{E}_{2}$ treatment increased teat lengths, but $\mathrm{E}_{2}$ administration and feeding for an increased rate of gain actually decreased future milk yield by 5.2 and $7.1 \%$, respectively. An increase in teat length as a result of $\mathrm{E}_{2}$ treatment or exposure to $\mathrm{E}_{2}$ in the diet has been used as a noninvasive bioindex for $\mathrm{E}_{2}$ activity, and the effect has been noted in studies with beef heifers (Moran et al., 1991) and lambs (Ellis et al., 1998; Mahgoub et al., 2001).

To test our hypothesis, we fed calves 2 distinct preweaning diets. We have reported the effects of these diets on general body growth and the development of multiple organs (Geiger et al., 2016). In this report, we describe the effects of these dietary treatments on the udder, mammary PAR, and mammary fat pad (MFP). We also describe the effects of $\mathrm{E}_{2}$ (Preston, 1999) administered during the 2 weeks postweaning on the same mammary parameters. We hypothesized that calves fed a higher plane of nutrition preweaning and given $\mathrm{E}_{2}$ immediately postweaning would experience increased mammary gland development compared with controls.

\section{MATERIALS AND METHODS}

This experiment was conducted under the review and approval of the Virginia Polytechnic Institute and State University Institutional Animal Care and Use Committee (\#14-045-DASC).

\section{Animal Handling and Experiment Design}

The experimental design and animal handling were as previously described (Geiger et al., 2016). Briefly, calves were assigned to 1 of 2 experimental milk replacers ( $\mathrm{n}=18$ per group): (1) a restricted milk replacer (R; $20 \%$ CP, $20 \%$ fat; Southern States Cooperative Inc., Richmond, VA) fed at $0.45 \mathrm{~kg} /$ calf per day, or (2) an enhanced milk replacer (EH; $28 \%$ CP, $25 \%$ fat; Land O'Lakes Animal Milk Products Co., Shoreview, MN) fed at $1.13 \mathrm{~kg} /$ calf per day. Starter $(22 \%$ CP, $3.5 \%$ fat, $8.0 \%$ crude fiber; Southern States Cooperative Inc.) was offered at the end of wk 4 of the trial. A subset of calves ( $\mathrm{n}=6$ per diet) was killed upon weaning to assess the effects of diet on mammary gland development. The remaining calves $(\mathrm{n}=24)$ were given an $\mathrm{E}_{2}$ implant (Compudose, Elanco Animal Health, Greenfield, IN) or a placebo implant at weaning. This produced the following treatment groups ( $\mathrm{n}=6$ per treatment): (1) calves fed a restricted diet and given a placebo implant $(\mathbf{R})$, (2) calves fed a restricted diet and given an $\mathrm{E}_{2}$ implant (R-E2), (3) calves fed an enhanced diet and given a placebo implant $(\mathbf{E H})$, and (4) calves fed an enhanced diet and given an $\mathrm{E}_{2}$ implant (EH-E2). After 2 wk of $\mathrm{E}_{2}$ treatment, all remaining animals were killed to assess the effect of $\mathrm{E}_{2}$ on calves fed the 2 different diets.

\section{Sample Collection}

Noninvasive mammary gland measures were collected once weekly and included front and rear teat length, distance from front to rear teats, distance between front teats, distance between rear teats, and gland length and width. All mammary measures (e.g., distance be- 
tween front and rear teats) that resulted in more than 1 measurement in a given week were averaged for a given calf. Unless presented for a specific weekly period, measurements for each calf represent the average across the entire period (i.e., pre- or postweaning). The same researcher collected measurements on a weekly basis.

A dual-energy x-ray absorptiometry (DXA) machine was available for use during this trial. Due to increased interest in gauging mammary gland development noninvasively (Esselburn et al., 2015), we used a Lunar Prodigy Advance DXA machine $(\mathrm{PA}+130744$, GE Healthcare, Little Chalfont, UK) to assess mammary tissue composition differences after the animals were killed. Scanning of each udder half lasted approximately $4 \mathrm{~min}$. At the conclusion of all scans, the software was calibrated to ensure that all tissue analyzed was appropriately identified. This was done using the point function to highlight all tissue containing areas of the udder half. The DXA scanning provided values for tissue fat content (\%), tissue weight $(\mathrm{g})$, fat weight (g), and lean tissue weight (g). Following the initial DXA scan, the skin was removed from each udder half and the process was repeated. Because the pattern of response was essentially identical between udder halves with or without skin, only the findings from the scan without skin were reported, and correlations between DXA and biochemical determinations of fat content were calculated.

\section{Tissue Collection}

Heifers were euthanized as previously reported (Geiger et al., 2016). The udder was removed within 10 min after exsanguination and bisected medially into left and right halves. The left half was enclosed in plastic wrap and aluminum foil, snap frozen by immersion in liquid nitrogen, and stored at $-80^{\circ} \mathrm{C}$. Later, the skin was removed from the left half; the PAR and MFP were dissected, separated, and weighed. Representative PAR and MFP samples were selected and pulverized using a freezer mill (Freezer/Mill 6850, SPEX Sample Prep, Metuchen, NJ). The freezer mill was kept cool using liquid nitrogen. Samples were processed using the following sequence: 5 min cool down, 4 min run time, 1 min cool down, 4 min run time. The resulting powders for both the PAR and MFP tissue were stored at $-80^{\circ} \mathrm{C}$ until subsequent analysis.

At the time of slaughter, the right rear mammary gland was used to collect samples of PAR and MFP tissue that were immediately frozen in liquid nitrogen and stored for future gene expression analysis. Portions of the right rear quarter were also dissected to provide PAR explants for subsequent incubations. The right fore quarter was used to collect tissue samples that were fixed for future histological analysis and immunohistochemistry. Briefly, the dissected parenchymal mass with the teat attached was partially bisected or butterflied (depending on size) and immersed in a container of fixative as described in a previous study (Tucker et al., 2016). Examples of dissected, fixed tissues are shown in Geiger et al. (2016). After fixation, these tissues were then subsampled to provide PAR from near the teat, midway to the outer region of the PAR, and at the margin between the outermost PAR region and the surrounding MFP. For some of the R group heifers, the PAR mass was too small justify subsampling, so the embedded tissues encompassed each of the 3 tissue regions in individual paraffin blocks.

For measurement of DNA and protein, $250 \mathrm{mg}$ samples of pulverized tissue for both MFP and PAR were homogenized using a Pro 200 homogenizer (Pro Scientific Inc., Oxford, CT). Briefly, pulverized tissue was homogenized in $800 \mu \mathrm{L}$ of a high-salt buffer $(0.05 \mathrm{M}$ $\mathrm{Na}_{2} \mathrm{HPO}_{4}+2 \mathrm{M} \mathrm{NaCl}+0.002 M \mathrm{Na}_{2}$ EDTA, pH 7.4). The homogenizer probe was washed in $700 \mu \mathrm{L}$ of the same buffer and combined with the initial homogenate. Homogenates were centrifuged at $100 \times g$ for $10 \mathrm{~min}$ at $4^{\circ} \mathrm{C}$, and the supernatant was used for subsequent analyses.

\section{DNA Content}

The DNA content of PAR and MFP tissue was measured as previously described by Daniels et al. (2009b). Samples of the supernatant $(2 \mu \mathrm{L})$ were transferred to a tube containing $2 \mathrm{~mL}$ of assay solution. The assay solution was composed of $100 \mu \mathrm{L}$ of $1 \mathrm{mg} / \mathrm{mL}$ Hoechst $\mathrm{H} 33258+10 \mathrm{~mL}$ of $10 \mathrm{~m} M$ Tris- $\mathrm{Cl}+90 \mathrm{~mL}$ of $\mathrm{H}_{2} \mathrm{O}$. Triplicate samples were measured using a Hoefer DQ 300 fluorimeter (Hoefer Inc., San Francisco, CA). Intraassay CV averaged 5.8\%.

\section{Protein Content}

Protein content of PAR and MFP tissue was determined using the BCA Protein Assay Kit (product \#23225, Pierce, Rockford, IL). After completion of the provided standard curve, $10 \mu \mathrm{L}$ of each sample supernatant was combined with $200 \mu \mathrm{L}$ of working reagent in duplicate wells of a 96-well plate. After loading, the plate was gently mixed $(30 \mathrm{~s})$ and incubated at $37^{\circ} \mathrm{C}$ for 30 min. Absorbency was measured using a $\mu$ Quant plate reader ( $\mu$ Quant Inc., Bio-Tek Instruments, Winooski, VT) at a wavelength of $562 \mathrm{~nm}$. Duplicate readings with a CV $\leq 10.0 \%$ were accepted. Samples were repeated as necessary. 


\section{Fat Content}

Fat content of both PAR and MFP tissue was determined using a hexane-isopropanol extraction as described by Daniels et al. (2009b), except that the extraction was initiated using pulverized tissue samples rather than homogenate. Duplicate pulverized tissue samples were assayed for all MFP and PAR samples from each calf. Briefly, acid-washed glass tubes with Teflon-lined screw caps were used for the extractions. After recording initial tube weights, $0.5 \mathrm{~g}$ of pulverized MFP or $0.25 \mathrm{~g}$ of PAR was weighed into a $25-\times$ $150-\mathrm{mm}$ test tube. Each sample-containing tube then received $18 \mathrm{~mL}$ of hexane-isopropanol (3:2 ratio of hexane to isopropanol) per gram of tissue. Tubes were then capped and vortexed for $30 \mathrm{~s}$. Thereafter, $12 \mathrm{~mL} / \mathrm{g}$ of a sodium sulfate solution $\left(1 \mathrm{~g}\right.$ of $\mathrm{Na}_{2} \mathrm{SO}_{4}$ in $15 \mathrm{~mL}$ of $\mathrm{H}_{2} \mathrm{O}$ ) was added to each tube. Tubes were vortexed for $30 \mathrm{~s}$, left to sit until the phases separated ( $\sim 5 \mathrm{~min})$, and vortexed for $30 \mathrm{~s}$. All sample-containing tubes were then centrifuged at $1,000 \times g$ for $5 \mathrm{~min}$ at $4^{\circ} \mathrm{C}$. Then, the upper solvent phase was transferred to the small test tube using a glass Pasteur pipette. After the initial lipid extraction, samples were re-extracted and the resulting solvent layers combined in a single tube. Tubes with combined solvent layers were then loaded into an N-Evap (Organomation Associates Inc., Berlin, MA) with a warm water bath at $40^{\circ} \mathrm{C}$, where the solvent was evaporated under a stream of nitrogen. After evaporation, the difference between the initial and final weights of the tubes was used to estimate the lipid content of the tissue samples.

\section{Histological Evaluation}

Samples of fixed parenchymal tissue were embedded in paraffin and tissue sections subsequently prepared, dewaxed, and stained with hematoxylin and eosin for general histology as described in previous studies (Velayudhan et al., 2012; Tucker et al., 2016).

\section{Statistical Analysis}

Statistical analysis was conducted as previously described (Geiger et al., 2016) using PROC GLIMMIX in SAS version 9.4 (SAS Institute Inc., Cary, NC). For noninvasive mammary measures, main effects included treatment, time (week), batch (i.e., shipment: calves arrived in 3 shipments for trial; Geiger et al., 2016), and associated interactions. Data with multiple measures per calf (week) were analyzed as repeated measures when applicable. For slaughter data, main effects included treatment, slaughter date, and the associated interaction. Calf ID was treated as a random variable for all analyses. Batch, treatment, and their interaction were treated as fixed effects, whereas residual error was treated as a random effect. Variables that did not contribute significantly to the model were removed. Significance was declared when $P<0.05$.

\section{RESULTS AND DISCUSSION}

\section{Noninvasive Mammary Gland Measurements}

Overall, the noninvasive mammary gland measures we employed to evaluate changes in udder development were highly variable between and within treatments. We observed no significant differences for distance between front and rear teats $(P=0.40)$ or distance between front teats $(P=0.54)$. Distance between rear teats was affected by diet: EH calves had a greater distance between rear teats than $\mathrm{R}$ calves during the preweaning period ( 3.63 vs. $3.27 \mathrm{~cm}, P \leq 0.05$ ). Gland length was greater in $\mathrm{EH}$ than in $\mathrm{R}$ calves during the preweaning period (10.29 vs. $9.21 \mathrm{~cm}$, respectively; $P$ $\leq 0.01)$. Postweaning gland width was also greater in EH than R calves (11.18 vs. $10.25 \mathrm{~cm} ; P \leq 0.01$ ). Data reported for the noninvasive measures above are the average values over the entire preweaning period. These data (i.e., larger values for $\mathrm{EH}$ calves) correspond with differences measured for biochemical parameters and dissected tissue mass, but alone are of limited value.

Throughout most of the trial, we found no detectable differences in the length of front $(P=0.26)$ or rear $(P$ $=0.58$ ) teats due to dietary treatment (entire preweaning period). However, on wk 8 (Figure 1), EH-fed calves had longer front and rear teats $(P \leq 0.10$ and $\leq 0.05)$. An increase in teat length due to $\mathrm{E}_{2}$ became apparent during the second week of treatment for both front and rear teats (wk 10; Figure 1). Length of both front and rear teats was increased $(P \leq 0.05)$ in $\mathrm{E}_{2}$-treated calves by wk 10 . These results are similar to reports by Lammers et al. (1999) and Moran et al. (1991) showing calves given $\mathrm{E}_{2}$ had longer teats. The increase in teat length we observed confirms that the $\mathrm{E}_{2}$ treatment applied to these calves was sufficient to elicit a mammary tissue response.

Noninvasive mammary gland measurements are an attractive approach for gauging mammary gland development because they do not require animal killing or surgery. However, measures such as distance between teats are of limited value because they have modest correspondence with larger udders. Still, to the best of our knowledge, this is the first study indicating that diet can influence teat length in heifers this early in life. It may be that the dietary differences reflected 
A

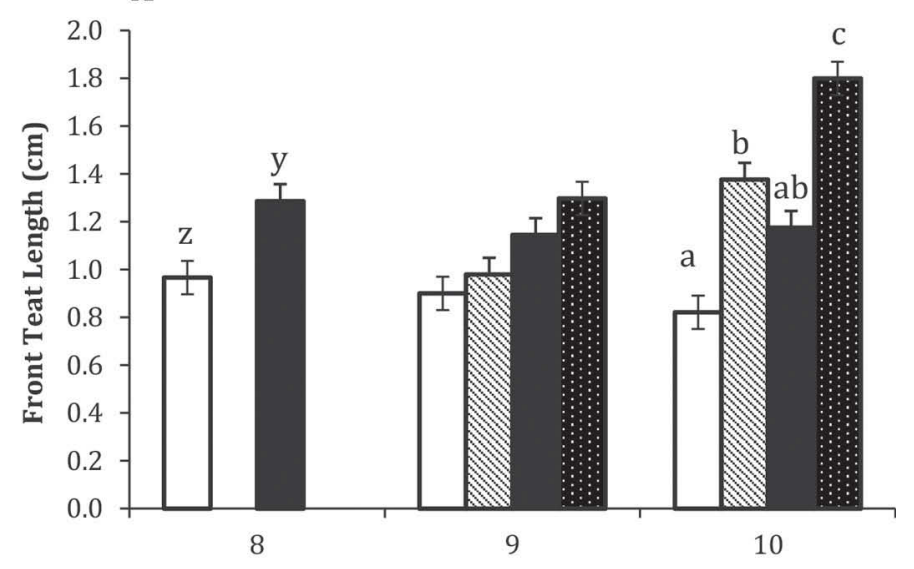

B

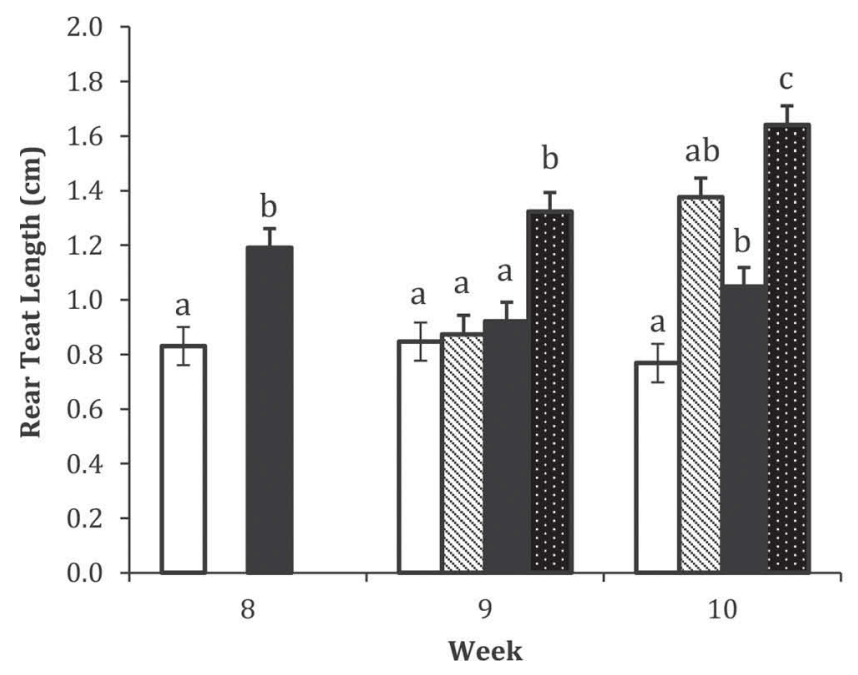

Figure 1. Front and rear teat length of Holstein heifer calves fed either a control diet or a higher plane of nutrition preweaning with or without exogenous estrogen administration immediately postweaning. (A) Front teat length during wk 8, 9, and 10 to assess diet and estrogen effects, and (B) rear teat length during wk 8, 9, and 10 to assess diet and estrogen effects. White bar indicates restricted diet ( $\mathrm{R})$, black bar indicates enhanced diet $(\mathrm{EH})$, bar with diagonal lines indicates restricted diet and exogenous estrogen (R-E2), and black bar with white dots indicates enhanced diet and exogenous estrogen (EH-E2) Differing letters $(\mathrm{a}, \mathrm{b}, \mathrm{c})$ indicate treatment differences $(P \leq 0.05)$; differing letters $(\mathrm{y}, \mathrm{z})$ indicate treatment tendencies $(P \leq 0 . \overline{1})$. Data given as $\mathrm{LSM} \pm \mathrm{SEM}$.

the marked increase in MFP mass (see below) and a presumptive increase in adipocytes (i.e., greater MFP DNA). This could allow for enhanced local aromatase activity (To et al., 2015) and a localized increase in $\mathrm{E}_{2}$ in $\mathrm{EH}$ calves, and thus an effect on teat length.

Figure 2 provides results obtained by DXA scanning of udder halves collected at the time of slaughter. It is clear that mammary glands of EH-fed calves had more mammary fat, a result also reflected in the biochemical analyses of the MFP (see below). Additionally, EH-E2 calves had the greatest amount of mammary fat among calves killed at $10 \mathrm{wk}$, which was also confirmed via biochemical analysis. Perhaps most interestingly, we sought to determine correlations between scanning data, dissection results, and biochemical measures of tissue composition. Correlation data indicated a highly positive correspondence between mammary gland fat determined biochemically and by DXA for all treatments $(r=0.94$, without skin). However, we found no meaningful correlation between mammary gland lean tissue (as determined by DXA) and either the mass or DNA content of the PAR. Thus, DXA data were not useful in determining the amount of PAR in the developing mammary glands of these young prepubertal calves.

In their recent report, Esselburn et al. (2015) describe some of the history of the use of udder measurements and palpation to evaluate mammary development in heifer calves and demonstrate the utility of ultrasound for evaluating udder and mammary development in young heifers. We took advantage of available DXA scanning equipment to determine if this tool could be used to evaluate udder development in these heifers. This methodology has been commonly used in animal experiments (Scholz et al., 2015) and can determine adipose content. Differences in mammary adipose tissue from our animals might be obtainable via DXA.

These data indicate that DXA scanning can be used to determine the fat content of the mammary gland. However, the mammary gland was removed from the body of the calf before scanning, and results presented are from de-skinned mammary glands, although results were similar with and without skin. It is uncertain if DXA could be used to estimate udder fat content in intact animals. The goal of ultrasound and similar (i.e., DXA) technologies is to eliminate the need to kill animals in experiments. If DXA approves an effective means of gauging the developing mammary gland in future experiments, the need to kill animals may be reduced. In this trial, however, animals were killed at trial conclusion because validating DXA technology was not the primary focus; it was an opportunity presented near the time of planned slaughter. However, there is much recent interest in use of a variety of noninvasive techniques, including DXA, to determine tissue composition in multiple species of animals and in selected organs and tissues (Scholz et al., 2015).

\section{Gross Mammary Gland Data}

After gross udder weight was recorded (Geiger et al., 2016), the udder was bisected and the left half saved for biochemical analysis. Data for the mass of udder tissue 

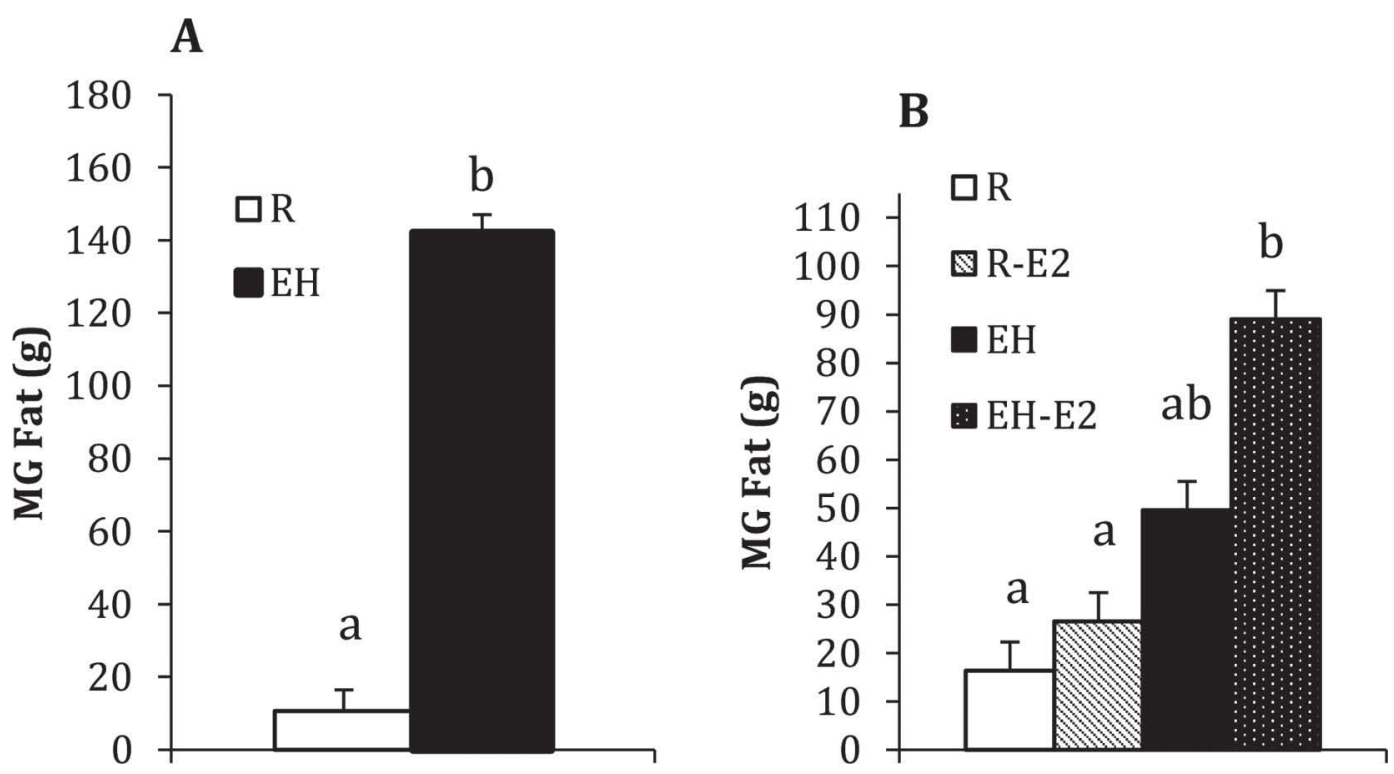

Figure 2. Dual x-ray absorptiometry data of trimmed mammary glands (MG) without skin from Holstein heifer calves fed either a restricted diet or a higher plane of nutrition preweaning with or without exogenous estrogen administration immediately postweaning. (A) Mammary gland fat weight $(P<0.01)$ for calves fed either a restricted or enhanced diet preweaning (killed in wk 8$)$, and $(\mathrm{B})$ mammary gland fat weight for calves fed a restricted or enhanced diet preweaning with or without exogenous estrogen postweaning (killed in wk 10; $P<0.01$ ). White bar indicates restricted diet $(\mathrm{R})$, black bar indicates enhanced diet $(\mathrm{EH})$, bar with diagonal lines indicates restricted diet and exogenous estrogen (R-E2), and black bar with white dots indicates enhanced diet and exogenous estrogen (EH-E2). Differing letters (a, b) indicate treatment differences $(P \leq 0.01)$. Data given as LSM \pm SEM.

collected at the time of weaning are given in Figure 3. Trimmed mammary gland weights were 5.2-fold greater $(P \leq 0.01)$ for EH-fed than for R-fed calves. The difference was even more dramatic $(7.3$-fold; $P \leq 0.01)$ for the mass of dissected mammary PAR tissue. Similarly, the mass of the MFP was also markedly increased in EH-fed calves compared with R-fed calves (5.9-fold; $P$ $\leq 0.01)$. Upon adjusting for BW, EH-fed calves had more total mammary tissue than R-fed calves (1.3 vs. $0.39 \mathrm{~g} / \mathrm{kg}$ of BW; $P \leq 0.01)$. Additionally, EH-fed calves had more mammary PAR $(0.07$ vs. $0.02 \mathrm{~g} / \mathrm{kg}$ of BW; $P \leq 0.05)$ and MFP $(1.13$ vs. $0.30 \mathrm{~g} / \mathrm{kg}$ of BW; $P$ $<0.01)$ than R-fed calves.

Mammary data describing the effects of $\mathrm{E}_{2}$ and diet at the wk 10 slaughter are given in Figure 4. The mass of the trimmed mammary gland was greater $(P<$ 0.01 ) in EH-E2 heifers than in all other groups, and we observed a progressive increase in R, EH, R-E2, and EH-E2 heifers. Calves in the EH-E2 treatment group had more PAR tissue than all other calves on trial and more PAR tissue than EH-fed calves $(P<$ 0.05). The difference in PAR tissue mass between R-E2 and $\mathrm{R}$ calves was nonsignificant. Calves given EH-E2 also had greater MFP weights than all other calves on trial and had greater MFP weights than EH-fed calves $(P<0.01)$. Upon adjustment for BW, calves in the EH-E2 treatment had more total mammary tissue than all other calves on trial, most notably EH-fed calves $(1.26$ vs. $0.72 \mathrm{~g} / \mathrm{kg}$ of $\mathrm{BW} ; P<0.01)$. Additionally, R-E2 calves had more mammary gland tissue than R-fed calves $(0.73$ vs. $0.41 \mathrm{~g} / \mathrm{kg}$ of $\mathrm{BW}$, respectively; $P<0.01)$. Calves in the EH-E2 treatment had more PAR per unit of BW than calves in all other treatment groups. The amount of MFP tissue per unit of BW responded similarly to PAR tissue.

Our data clearly demonstrate that preweaning nutrition can dramatically affect the overall development of the bovine mammary gland. In particular, these data show that compared with restricted feeding, enhanced feeding stimulates growth of both the MFP and the mammary PAR. Moreover, our hypothesis that mammary tissue derived from enhanced-fed calves is better able to respond to mammogenic stimuli was supported by our observations of maximum mammary development (i.e., mass of mammary PAR) in enhanced-fed heifers given $\mathrm{E}_{2}$. Restricted-fed heifers were also capable of responding to exogenous $\mathrm{E}_{2}$, but the response was blunted compared to the robust effect of $\mathrm{E}_{2}$ stimulation in enhanced-fed heifers. We hope to uncover underlying mechanisms via gene expression analysis of the PAR explants incubated at the time of slaughter, as well as samples of snap-frozen PAR and MFP tissue.

Data herein agree with previous research indicating that feeding a higher plane of nutrition through milk 

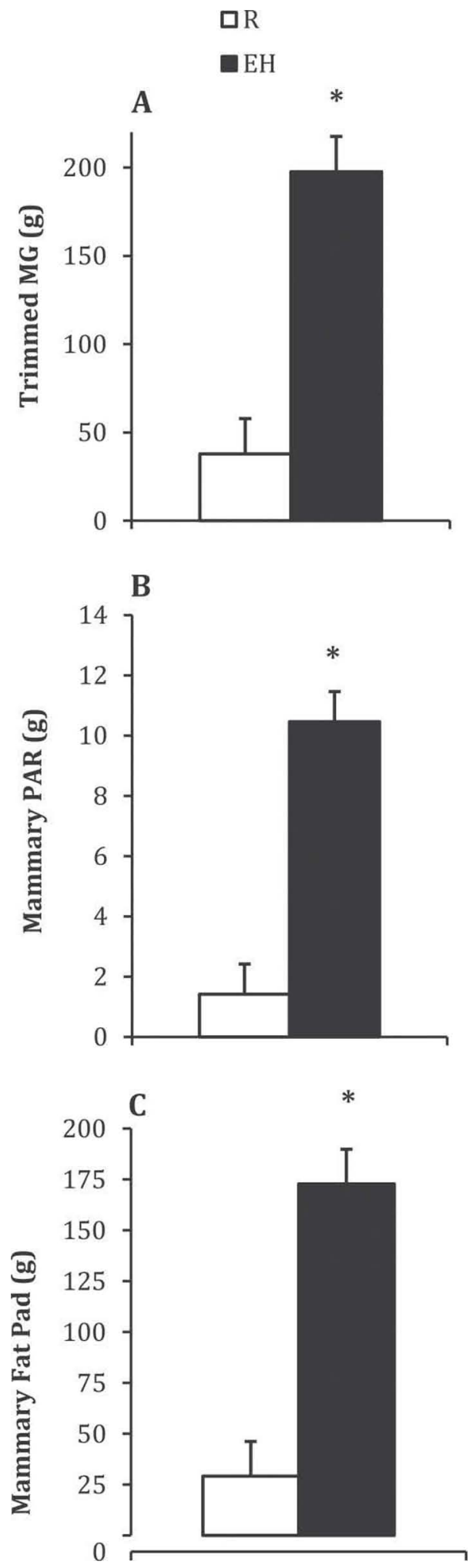

Figure 3. Trimmed mammary gland (MG) weights of Holstein heifer calves fed either a control diet or a higher plane of nutrition preweaning. (A) Trimmed mammary gland weight, (B) mammary parenchyma (PAR) weight, and (C) mammary fat pad weight. White bar indicates restricted diet $(\mathrm{R})$ and black bar indicates enhanced diet (EH). ${ }^{*}$ Dietary difference $(P \leq 0.01)$. Data given as LSM \pm SEM.
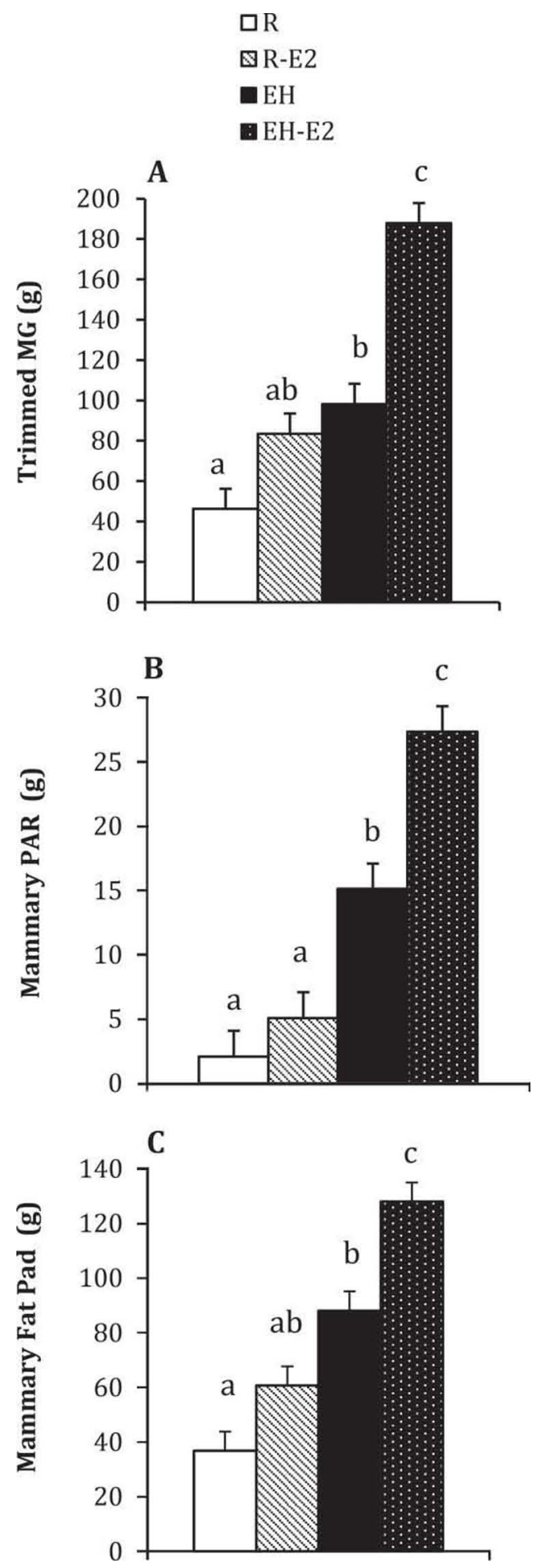

Figure 4. Trimmed mammary gland (MG) weights of Holstein heifer calves fed either a control diet or a higher plane of nutrition preweaning with or without exogenous estrogen administration immediately postweaning. (A) Trimmed mammary gland weight, (B) mammary parenchyma (PAR) weight, and (C) mammary fat pad weight. White bar indicates restricted diet $(\mathrm{R})$, black bar indicates enhanced diet $(\mathrm{EH})$, bar with diagonal lines indicates restricted diet and exogenous estrogen (R-E2), and black bar with white dots indicates enhanced diet and exogenous estrogen (EH-E2). Differing letters (a, b, c) indicate treatment differences $(P \leq 0.05)$. Data given as LSM \pm SEM. 
replacer during the preweaning period increases total mammary gland weight (Brown et al., 2005). The most dramatic difference between previous reports and the present data were the 7.3-fold increase in mammary PAR mass observed between EH and $\mathrm{R}$ calves. Few data exist indicating that altering the plane of nutrition during the preweaning period can lead to the dramatic increase observed in the present study. Brown et al. (2005) did find that offering a higher plane of nutrition increased mammary PAR mass 3.8-fold, compared with the 7.3-fold difference observed in our trial. This may simply reflect the greater difference between treatments employed in this study. The 5.9-fold increase in MFP weight observed in this study was consistent with several other trials (Thibault et al., 2003; Meyer et al., 2006b; Daniels et al., 2009b).

Providing $\mathrm{E}_{2}$ postweaning to the calves allowed us to test our hypothesis and determine if calves fed a higher plane of nutrition were better able to respond to mammogenic stimuli. Enhanced-fed calves given $\mathrm{E}_{2}$ postweaning did indeed exhibit an increase in mammary gland PAR and MFP tissue weight, whereas R-fed calves did not. Analysis of Figure 4 appears to indicate that change in PAR weights as a result of $\mathrm{E}_{2}$ were similar for both dietary treatments. Still, due to the lower PAR weight that resulted from the $\mathrm{R}$ diet, the difference in PAR weight was not significant between $R$ and R-E2 calves and the difference between EH and EH-E2 calves was significant. For this reason, we believe that these results support our hypothesis (i.e., calves on a higher plane of nutrition would be better able to respond to mammogenic stimulation). Future analyses may help us identify cellular and physiological mechanisms to explain these differences in tissue development.

\section{Mammary Gland Composition}

Mammary gland composition for both the MFP and PAR of calves slaughtered at weaning are shown in Table 1. Protein in the MFP was affected by diet, with $\mathrm{R}$ calves having a greater protein concentration than EH calves $(P \leq 0.01)$. However, EH calves had greater total protein in the MFP than $\mathrm{R}$ calves $(P \leq$ 0.01 ). Mammary gland fat pad DNA concentration was not affected by diet, but MFP total DNA was 5.4 -fold greater for $\mathrm{EH}$ calves than for $\mathrm{R}$ calves $(P \leq 0.01)$. Fat concentration in the MFP was greater for $\mathrm{EH}$ calves than for $\mathrm{R}$ calves $(P<0.01)$, as was total fat in the $\operatorname{MFP}(P \leq 0.01)$.

Protein concentration in the PAR was unaffected by diet, but total protein was markedly greater (6.8-fold; $P \leq 0.01)$ for $\mathrm{EH}$ calves than for $\mathrm{R}$ calves. Additionally, PAR DNA concentration was unaffected by diet, but total DNA in the PAR was 7.6-fold greater for EH calves $(P \leq 0.05)$. Neither PAR fat concentration nor total fat were effected by dietary treatment.

Biochemical composition of the MFP and PAR of calves given either an $\mathrm{E}_{2}$ or placebo implant immediately postweaning are shown in Table 2. Protein concentration in the MFP was unaffected by postweaning treatment. However, total protein in the MFP was increased in EH-E2 calves compared to all other calves $(P \leq 0.01)$. DNA concentration in the MFP was also unaffected by postweaning treatment, but total DNA in the MFP was greater in $\mathrm{EH}$ and EH-E2 calves than in $\mathrm{R}$ and R-E2 calves $(P<0.05)$, with R-E2 calves tending to have more total MFP DNA than R-fed calves $(P$ $<0.10)$. Fat concentration in the MFP was higher $(P$ $\leq 0.05)$ in EH-E2 calves than in EH, R, or R-E2 calves, and EH-E2 calves had greater total fat $(P \leq 0.05)$ in the MFP than EH, R, and R-E2 calves.

Enhanced-fed calves given $\mathrm{E}_{2}$ had more PAR protein than all other calves $(P \leq 0.05)$. DNA concentration in the PAR was unaffected by postweaning treatment, but total DNA was greater for EH-E2 calves than for EH, R-E2, and $\mathrm{R}$ calves $(P<0.01)$. Fat concentration in the PAR was greatest for R-fed calves than for all other treatment groups $(P \leq 0.01)$.

\section{Histological Appearance of Parenchyma}

The general architecture of the epithelial appeared normal in all animals, but we found dramatic differ-

Table 1. Composition of the mammary fat pad and parenchyma at weaning of Holstein heifer calves fed either a control diet or a higher plane of nutrition

\begin{tabular}{lccc}
\hline & \multicolumn{2}{c}{ Treatment $^{1}$} & \\
\cline { 2 - 3 } Item & $\mathrm{R}$ & EH & SEM \\
\hline Mammary fat pad & & & \\
Total protein (g) & $0.46^{\mathrm{a}}$ & $2.11^{\mathrm{b}}$ & 0.2 \\
Protein (mg/g) & $15.6^{\mathrm{a}}$ & $12.2^{\mathrm{b}}$ & 1.1 \\
Total DNA (mg) & $4.1^{\mathrm{a}}$ & $22.5^{\mathrm{b}}$ & 6.18 \\
DNA (mg/g) & 0.14 & 0.13 & 0.14 \\
Total fat (g) & $3.27^{\mathrm{a}}$ & $116^{\mathrm{b}}$ & 13.7 \\
Fat (mg/g) & $112^{\mathrm{a}}$ & $667^{\mathrm{b}}$ & 32.2 \\
Mammary parenchyma & & & \\
Total protein (g) & $0.20^{\mathrm{a}}$ & $1.36^{\mathrm{b}}$ & 0.3 \\
Protein (mg/g) & 14.1 & 13.0 & 1.8 \\
Total DNA (mg) & $2.7^{\mathrm{a}}$ & $20.4^{\mathrm{b}}$ & 6.33 \\
DNA (mg/g) & 1.87 & 1.95 & 0.53 \\
Total fat (g) & 0.15 & 2.10 & 2.18 \\
Fat (mg/g) & 106 & 201 & 69.8 \\
\hline
\end{tabular}

$\overline{\mathrm{a}, \mathrm{b}}$ Differing superscripts within a row indicate diet differences $(P<$ $0.05)$.

${ }^{1} \mathrm{R}=$ calves fed restricted milk replacer $(20 \% \mathrm{CP}, 20 \%$ fat $)$ at a rate of $0.45 \mathrm{~kg} / \mathrm{d}$; EH $=$ calves fed enhanced milk replacer $(28 \% \mathrm{CP}, 25 \%$ fat) at a rate of $1.13 \mathrm{~kg} / \mathrm{d}$. 
Table 2. Composition of the mammary fat pad and parenchyma at wk 10 of Holstein heifer calves fed either a control diet or a higher plane of nutrition preweaning, with or without exogenous estrogen administration immediately postweaning

\begin{tabular}{lccccc}
\hline & \multicolumn{4}{c}{ Treatment $^{1}$} \\
\cline { 2 - 4 } Item & $\mathrm{R}$ & $\mathrm{R}-\mathrm{E} 2$ & $\mathrm{EH}$ & $\mathrm{EH}-\mathrm{E} 2$ & \multirow{2}{*}{ SEM } \\
\hline Mammary fat pad & & & & \\
Total protein (g) & $0.7^{\mathrm{a}}$ & $1.1^{\mathrm{ab}}$ & $1.6^{\mathrm{b}}$ & $2.7^{\mathrm{c}}$ & 0.3 \\
Protein (mg/g) & 18.7 & 18.8 & 17.3 & 20.8 & 2.7 \\
Total DNA (mg) & $6.6^{\mathrm{a}, \mathrm{y}}$ & $17.6^{\mathrm{a}, \mathrm{z}}$ & $30.8^{\mathrm{b}}$ & $29.4^{\mathrm{b}}$ & 3.08 \\
DNA (mg/g) & 0.18 & 0.29 & 0.35 & 0.23 & 0.08 \\
Total fat (g) & $8.0^{\mathrm{a}}$ & $14.2^{\mathrm{a}}$ & $24.4^{\mathrm{a}}$ & $64.1^{\mathrm{b}}$ & 9.5 \\
Fat (mg/g) & $217^{\mathrm{a}}$ & $234^{\mathrm{a}}$ & $277^{\mathrm{a}}$ & $501^{\mathrm{b}}$ & 38.6 \\
Mammary parenchyma & & & & \\
Total protein (g) & $0.05^{\mathrm{a}}$ & $0.16^{\mathrm{ab}}$ & $0.27^{\mathrm{b}}$ & $0.82^{\mathrm{c}}$ & 0.13 \\
Protein (mg/g) & $22.2^{\mathrm{yz}}$ & $30.8^{\mathrm{z}}$ & $18.1^{\mathrm{y}}$ & $30.1^{\mathrm{z}}$ & 3.4 \\
Total DNA (mg) & $3.9^{\mathrm{a}}$ & $9.8^{\mathrm{a}}$ & $26.1^{\mathrm{a}}$ & $59.1^{\mathrm{b}}$ & 11.18 \\
DNA (mg/g) & 1.87 & 1.93 & 1.73 & 2.16 & 0.15 \\
Total fat (g) & $0.8^{\mathrm{ab}}$ & $0.5^{\mathrm{a}}$ & $1.3^{\mathrm{ab}}$ & $3.1^{\mathrm{b}}$ & 0.71 \\
Fat (mg/g) & $385^{\mathrm{a}}$ & $98.4^{\mathrm{b}}$ & $86.1^{\mathrm{b}}$ & $113^{\mathrm{b}}$ & 36.8 \\
\hline
\end{tabular}

${ }^{a-c}$ Differing superscripts within a row indicate treatment differences $(P<0.05)$.

${ }^{\mathrm{y}, \mathrm{z}}$ Differing superscripts within a row indicate treatment tendencies $(0.05<P<0.10)$.

${ }^{1} \mathrm{R}=$ calves fed restricted milk replacer $(20 \% \mathrm{CP}, 20 \%$ fat $)$ at a rate of $0.45 \mathrm{~kg} / \mathrm{d} ; \mathrm{R}-\mathrm{E} 2=$ calves fed restricted milk replacer and given estrogen for 2 wk postweaning; $\mathrm{EH}=$ calves fed enhanced milk replacer $(28 \% \mathrm{CP}$, $25 \%$ fat) at a rate of $1.13 \mathrm{~kg} / \mathrm{d}$; and EH-E2 = calves fed enhanced milk replacer and given estrogen for $2 \mathrm{wk}$ postweaning.

ences in the degree of development across treatments. As can be seen in the gross anatomy of the PAR shown in Geiger et al. (2016), the epithelium of R calves was largely confined to surface folds immediately adjacent to the gland cistern. This was apparent in the simple single bisections needed to expose the entire glandular epithelium to fixative in $\mathrm{R}$ calves, compared with the multiple butterfly slices that were necessary expose the PAR tissue to fixative in EH and EH-E2 calves. Upon histological examination, the mucosal surface of the gland cistern was much larger and more extensively folded in EH calves and especially EH-E2 calves. As well, a much greater number of ductal structures had penetrated into the surrounding stromal tissue in $\mathrm{EH}$ as well as R-E2 and EH-E2 calves (Figure 5). Major ducts exposed to the luminal space of the gland cistern were usually 1 to 3 cell layers thick, in addition to a layer of presumptive myoepithelial cells along the basement membrane adjacent to the surrounding stromal tissue. Epithelial structures where invagination and expansion into the surrounding epithelium had occurred resembled many of the branched ductal structures observed in older prepubertal heifers (Capuco et al., 2002; Rowson et al., 2012). Others have noted differences in the relative epithelial development of the heifer mammary gland due to diet and or BW (Davis Rincker et al., 2008; Daniels et al., 2009b), but the degree of difference between $\mathrm{R}$ and $\mathrm{EH}$ treatments was markedly greater in this study. This is likely a reflection of the greater difference in the dietary treatments used in this experiment. We did not evaluate a set of calves killed at the beginning of the trial, but the appearance of the tissue of $\mathrm{R}$ group heifers was similar to tissue from calves of 2 to 3 weeks of age (Beaudry et al., 2016). Figure 5 illustrates the differences in the histological appearance of mammary tissue across treatments.

Previous studies have indicated the ease with which MFP mass and composition may be manipulated using dietary modifications. Lipid content of the MFP was increased in EH calves at weaning, leading to an increase in total MFP fat. This agrees with previous work that also noted increases in MFP lipid concentration and lipid mass produced by feeding a higher plane of nutrition (Daniels et al., 2009b). Additionally, R-fed calves had greater protein concentration in the MFP than EH calves, although EH calves had an increase in total MFP protein (as a result of MFP size). This contradicts previous work that reported an increase in MFP protein concentration as a result of feeding a higher plane of nutrition (Meyer et al., 2006b).

Mammary PAR composition is of particular interest when assessing the effects of feeding a higher plane of nutrition on mammary development and future milk potential. Mammary PAR composition was unaltered as PAR fat, protein, and DNA concentrations were unaffected by preweaning diet. However, total PAR protein and DNA were increased as a result of feeding a higher plane of nutrition. This finding agrees with Brown et al. (2005), who found that feeding a higher plane of nutrition preweaning could lead to an increase 

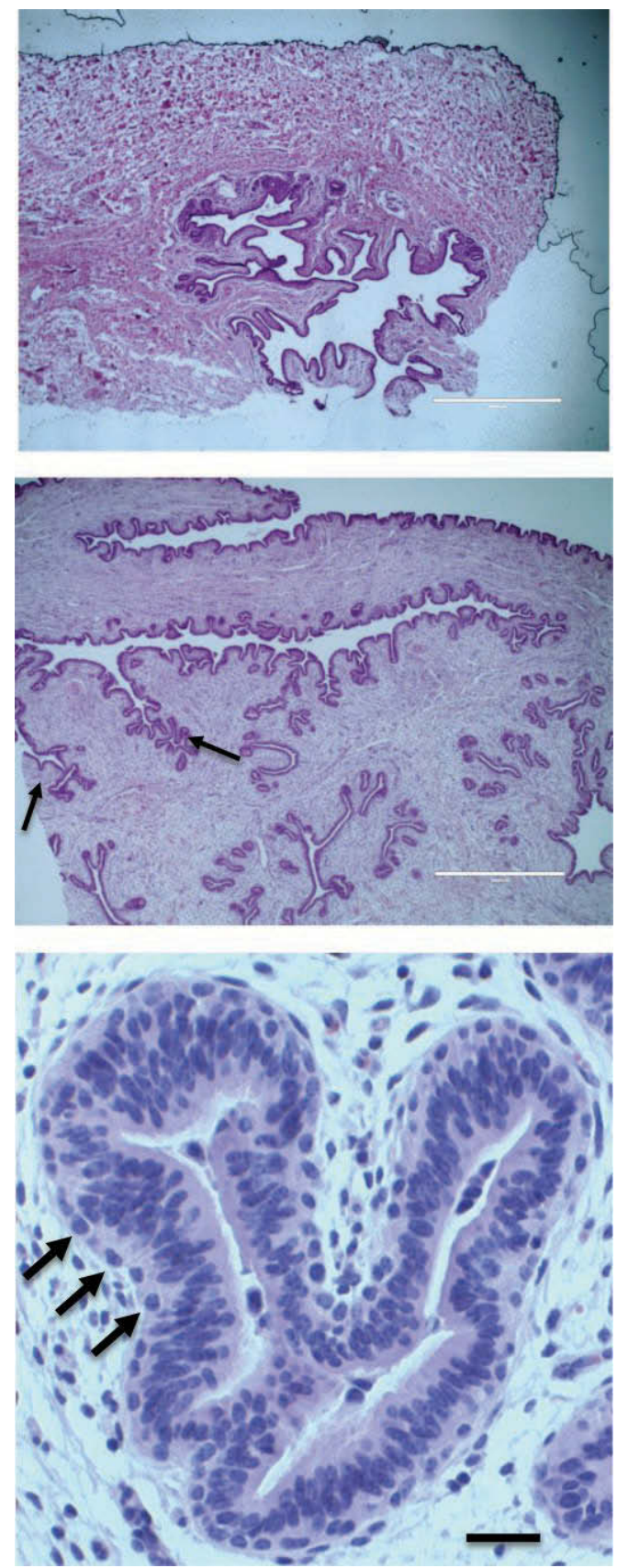

Figure 5. The upper panel provides a low power $(4 \times$ objective lens) view of mammary tissue from a restricted diet group calf sampled at 8 wk of age. This section through a region of the gland cistern shows minimal development of the epithelium beyond the folded epithelial layer of the gland cistern. The middle panel view, also taken with a $4 \times$ objective lens, illustrates the much more extensive development of the epithelium of a heifer from the enhanced diet and exogenous estrogen (EH-E2) group at 10 wk of age. Folding of the surface epithelium is extensive, and numerous ductal outgrowths are spreading into the underlying stromal tissue (arrows). The lower panel provides a higher magnification (20× objective lens) of a portion of a ductal outgrowth from an EH-E2 group heifer at 10 wk of age. Presumptive myoepithelial cells (arrows) are adjacent to the epithelial cell layer 1 to 3 cells in thickness. The magnification bar equals $1,000 \mu \mathrm{m}$ for the upper and middle panels and $50 \mu \mathrm{m}$ for the lower panel. Color version available online. in PAR DNA. The fact that protein, fat, and DNA concentrations were unaffected by diet in this trial suggests that the general cellular characteristics of the parenchymal tissue were not affected. However, it is also evident that the relative appearance of epithelial structures (i.e., penetration into the surrounding stromal tissue) was affected by diet (Figure 5). Given that there are also a substantial (and variable) number of stromal cells in the parenchymal compartment, it seems clear that the differences in epithelial appearance were not reflected in differences in DNA concentration. If future work shows that this type of feeding regimen does not decrease future milk yield potential, it may suggest that greater intake and growth rates preweaning can be achieved without negative consequences for mammary development and future performance.

Neither protein nor DNA concentration in the MFP were affected by postweaning treatment with $\mathrm{E}_{2}$. We found that DNA concentration in the PAR was unaffected by treatment, but total PAR DNA was greatest in EH-E2 calves. The fact that EH-E2 calves had an increase in total DNA compared with $\mathrm{EH}$ calves and that R-E2 calves did not experience a similar response (albeit a numerical increase) suggests that $\mathrm{E}_{2}$ was better able to stimulate epithelial cell growth in calves fed a higher plane of nutrition. This idea is reinforced by the fact that calves fed $\mathrm{EH}$ and given $\mathrm{E}_{2}$ postweaning not only had an increase in total DNA in the PAR, but also an increase in teat length, mammary gland weight, MFP weight, and PAR weight compared with all other calves on trial.

Demonstration that exogenous $\mathrm{E}_{2}$ can stimulate mammary development in prepubertal calves is not new, but we believe our data showing that preweaning feeding appears to enhance the responsiveness of the mammary gland to stimulation by $\mathrm{E}_{2}$ is novel. Thus, our hypothesis that $\mathrm{E}_{2}$ may act differentially in calves reared on different planes of nutrition is strongly supported. This suggests that nutritional mediation of mammary development is at least partially mediated by changes in the capacity of target cells to respond to mammogenic hormone stimulation.

In subsequent analyses, we will seek to determine cellular and molecular mechanisms that would explain observed differences in response to both diet and postweaning $\mathrm{E}_{2}$ treatment, and specifically if $\mathrm{E}_{2}$ signaling pathways are affected by diet.

\section{CONCLUSIONS}

Feeding calves differing planes of nutrition resulted in dramatic differences in mammary PAR (7.3-fold) and MFP (5.9-fold) without compromising the biochemical 
composition of the PAR. These results indicate clearly that preweaning diet can positively influence mammary gland development in Holstein heifers. The increase in mammary gland tissue and PAR mass observed when $\mathrm{E}_{2}$ was provided to $\mathrm{EH}$ calves but not $\mathrm{R}$ calves indicates that our fundamental hypothesis was correct. Additional research is underway to determine the molecular/ cellular mechanisms and pathways responsible for these differences. Dual x-ray absorptiometry proved an effective tool for analysis of mammary fat. However, DXA analysis could not effectively quantify mammary PAR, and the analysis was performed on removed mammary glands. It is yet to be determined if this technology can effectively measure mammary fat when the udder is still attached to the body wall of the animal.

\section{ACKNOWLEDGMENTS}

The authors acknowledge Land O'Lakes Inc. (St. Paul, MN) and Tom Earleywine (Land O'Lakes Inc.) for providing milk replacer and support during this trial. We also acknowledge grant support from USDANIFA-AFRI, 2016-67015-24575, Impact of Pre-Weaning Nutrition on Endocrine Induction of Mammary Development in Dairy Heifers, awarded to R. M. Akers, and 2016-67011-24703, predoctoral fellowship awarded to A. J. Geiger.

\section{REFERENCES}

Beaudry, K. L., C. L. M. Parsons, S. E. Ellis, and R. M. Akers. 2016. Localization and quantitation of macrophages, mast cells, and eosinophils in the developing bovine mammary gland. J. Dairy Sci. 99:796-804.

Berry, S. D., P. M. Jobst, S. E. Ellis, R. D. Howard, A. V. Capuco, and R. M. Akers. 2003. Mammary epithelial proliferation and estrogen receptor alpha expression in prepubertal heifers: Effects of ovariectomy and growth hormone. J. Dairy Sci. 86:2098-2105.

Brown, E. G., M. J. Vandehaar, K. M. Daniels, J. S. Liesman, L. T. Chapin, J. W. Forrest, R. M. Akers, R. E. Pearson, and M. S. Nielsen. 2005. Effect of increasing energy and protein intake on mammary development in heifer calves. J. Dairy Sci. 88:595-603.

Capuco, A. V., and R. M. Akers. 2010. Management and environmental influences on mammary gland development and milk production. Pages 259-292 in Managing the Prenatal Environment to Enhance Livestock Productivity. P. L. Greenwood, A. W. Bell, P. E. Vercoe and G. J. Viljoen, ed. Springer Science+Business Media B. V., Dordrecht, the Netherlands.

Capuco, A. V., S. Ellis, D. L. Wood, R. M. Akers, and W. Garett. 2002. Postnatal mammary ductal growth three-dimensional imaging of cell proliferatoin, effects of estrogen treatment, and expression of steroid receptors in prepubertal calves. Tissue Cell 34:143-154

Daniels, K. M., A. V. Capuco, M. L. McGilliard, R. E. James, and R. M. Akers. 2009b. Effects of milk replacer formulation on measures of mammary growth and composition in Holstein heifers. J. Dairy Sci. 92:5937-5950.

Daniels, K. M., M. L. McGilliard, M. J. Meyer, M. E. Van Amburgh, A. V. Capuco, and R. M. Akers. 2009a. Effect of body weight and nutrition on histological mammary development in Holstein heifers. J. Dairy Sci. 92:499-505.
Davis Rincker, L. E., M. S. Weber Nielsen, L. T. Chapin, J. S. Liesman, K. M. Daniels, R. M. Akers, and M. J. VandeHaar. 2008. Effects of feeding prepubertal heifers a high-energy diet for three, six, or twelve weeks on mammary growth and composition. J. Dairy Sci. 91:1926-1935.

Ellis, S., T. B. McFadden, and R. M. Akers. 1998. Prepubertal ovine mammary development is unaffected by ovariectomy. Domest. Anim. Endocrinol. 15:217-225.

Esselburn, K. M., T. M. Hill, H. G. Bateman II, F. L. Fluharty, S. J. Moeller, K. M. O'Diam, and K. M. Daniels. 2015. Examination of weekly mammary parenchymal area by ultrasound, mammary mass, and composition in Holstein heifers reared on 1 of 3 diets from birth to 2 months of age. J. Dairy Sci. 98:5280-5293.

Geiger, A. J., C. L. M. Parsons, R. E. James, and R. M. Akers. 2016. Growth, intake, and health of Holstein heifer calves fed an enhanced pre-weaning diet with or without exogenous estrogen. J. Dairy Sci. 99:3995-4004.

Heinrichs, A. J. 1993. Raising dairy replacements to meet the needs of the 21st century. J. Dairy Sci. 76:3179-3187.

Khan, M. A., D. M. Weary, and M. A. G. von Keyserlingk. 2011. Invited review: Effects of milk ration on solid feed intake, weaning, and performance in dairy heifers. J. Dairy Sci. 94:1071-1081.

Lammers, B. P., A. J. Heinrichs, and R. S. Kensinger. 1999. The effects of accelerated growth rates and estrogen implants in prepubertal Holstein heifers on estimates of mammary development and subsequent reproduction and milk production. J. Dairy Sci. $82: 1753-1764$

Mahgoub, O., G. K. Barrell, and A. R. Sykes. 2001. Effect of gender, gonadoectomy and oestradiol- $17 \beta$ on growth in lambs under grazing conditions. J. Agric. Sci. 137:351-364.

Meyer, M. J., A. V. Capuco, D. A. Ross, L. M. Lintault, and M. E. Van Amburgh. 2006a. Developmental and nutritional regulation of the prepubertal bovine mammary gland: II. Epithelial cell proliferation, parenchymal accretion rate, and allometric growth. J. Dairy Sci. 89:4298-4304.

Meyer, M. J., A. V. Capuco, D. A. Ross, L. M. Lintault, and M. E. Van Amburgh. 2006b. Developmental and nutritional regulation of the prepubertal heifer mammary gland: I. Parenchyma and fat pad mass and composition. J. Dairy Sci. 89:4289-4297.

Moran, C., J. F. Quirke, D. J. Prendiville, S. Bourke, and J. F. Roche. 1991. The effect of estradiol, trenbolone acetate, or zeranol on growth rate, mammary development, carcass traits, and plasma estradiol concentrations of beef heifers. J. Anim. Sci. 69:4249-4258.

Preston, R. L. 1999. Hormone containing growth promoting implants in farmed livestock. Adv. Drug Deliv. Rev. 38:123-138.

Purup, S., K. Sejrsen, J. Foldager, and R. M. Akers. 1993. Effect of exogenous bovine growth hormone and ovariectomy on prepubertal mammary growth, serum hormones and acute in vitro proliferative response of mammary explants from Holstein heifers. J. Endocrinol. 139:19-26.

Radcliff, R. P., M. J. Vandehaar, L. T. Chapin, T. E. Pilbeam, D. K. Beede, E. P. Stanisiewski, and H. A. Tucker. 2000. Effects of diet and injection of bovine somatotropin on prepubertal growth and first-lactation milk yields of Holstein cows. J. Dairy Sci. 83:23-29.

Rowson, A. R., K. M. Daniels, S. E. Ellis, and R. C. Hovey. 2012. Growth and development of the mammary glands of livestock: A veritable barnyard of opportunities. Semin. Cell Dev. Biol. 23:557566.

Scholz, A. M., L. Bünger, J. Kongsro, U. Baulain, and A. D. Mitchell. 2015. Non-invasive methods for the determination of body and carcass composition in livestock: Dual-energy X-ray absorptiometry, computed tomography, magnetic resonance imaging and ultrasound: Invited review. Animal 9:1250-1264.

Sejrsen, K., J. T. Huber, H. A. Tucker, and R. M. Akers. 1982. Influence of nutrition of mammary development in pre- and postpubertal heifers. J. Dairy Sci. 65:793-800.

Sinha, Y. N., and H. A. Tucker. 1969. Mammary development and pituitary prolactin level of heifers from birth through puberty and during the estrous cycle. J. Dairy Sci. 52:507-512. 
Soberon, F., E. Raffrenato, R. W. Everett, and M. E. Van Amburgh. 2012. Preweaning milk replacer intake and effects on long-term productivity of dairy calves. J. Dairy Sci. 95:783-793.

Thibault, C., D. Petitclerc, R. Spratt, M. Leonard, K. Sejrsen, and P. Lacasse. 2003. Effect of feeding prepubertal heifers with a high oil diet on mammary development and milk production. J. Dairy Sci. $86: 2320-2326$.

To, S. Q., K. C. Knower, V. Cheung, E. R. Simpson, and C. D. Clyne. 2015. Transcriptional control of local estrogen formation by aromatase in the breast. J. Steroid Biochem. Mol. Biol. 145:179-186.

Tucker, H. L. M., C. L. M. Parsons, S. Ellis, M. L. Rhoads, and R. M. Akers. 2016. Tamoxifen impairs prepubertal mammary development and alters expression of estrogen receptor $\alpha$ (ESR1) and progesterone receptors (PGR). Domest. Anim. Endocrinol. 54:95-105.

USDA. 2007. Dairy 2007, Part I: References of dairy health and management practices in the United States, 2007. USDA, Washington, DC.
Velayudhan, B. T., B. P. Huderson, S. E. Ellis, C. L. Parsons, R C. Hovey, A. R. Rowson, and R. M. Akers. 2015. Ovariectomy in young prepubertal dairy heifers causes complete suppression of mammary progesterone receptors. Domest. Anim. Endocrinol. $51: 8-18$.

Velayudhan, B. T., B. P. Huderson, M. L. McGilliard, H. Jiang, S. E. Ellis, and R. M. Akers. 2012. Effect of staged ovariectomy on measures of mammary growth and development in prepubertal dairy heifers. Animal 6:941-951.

Woodward, T. L., W. E. Beal, and R. M. Akers. 1993. Cell interactions in initiation of mammary epithelial proliferation by oestradiol and progesterone in prepubertal heifers. J. Endocrinol. 136:149-157.

Yart, L., V. Lollivier, P. G. Marnet, and F. Dessauge. 2014. Role of ovarian secretions in mammary gland development and function in ruminants. Animal 8:72-85. 